\title{
Depression, anxiety and stress and their associated social determinants in the Saudi college students
}

\author{
Shamim Mohammad, ${ }^{1}$ Ibrahim Waleed Almakran, ${ }_{1}$ Ahmad Saleh Al-Montashri, ${ }^{1}$ \\ Ammar Mohammed Mursi, ${ }^{1}$ Saleh Mohammed Alharbi, ${ }^{1}$ Tariq Sultan Pasha, ${ }^{2}$ Ismail Khalid ${ }^{3}$ \\ ${ }^{1}$ Department of Health Education and Health Promotion, and ${ }^{2}$ Department of Occupational \\ Health, Faculty of Public Health and Health Informatics, Umm Al-Qura University (UQU), Makkah; \\ ${ }^{3}$ Pervasive Development Disorder Center, Maternity \& Children Hospital, Ministry of Health, , \\ Makkah, Saudi Arabia
}

\begin{abstract}
Globally, students suffer from stress, anxiety, and depression in higher education and seek counselling since education process has negative impacts on mental health of some students. This study was aimed at measuring the depression, stress, and anxiety and their associated social determinants like (income, education, residence, marital status, and educational difficulties) in undergraduate students of Umm Al-Qura University (UQU). Arabic ver-
\end{abstract}

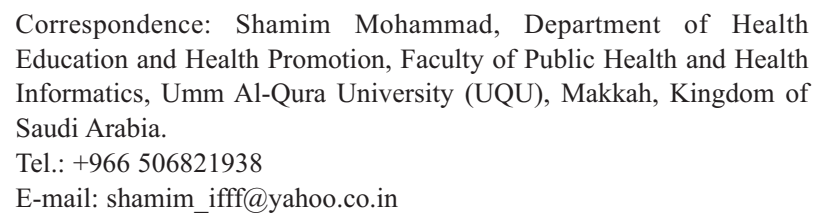

Key words: Stress; anxiety; depression; students; mental health.

Contributions: SM: principal investigator, data collection, data cleaning, data feeding into the SPSS, data analysis and manuscript preparation; IWA, ASAM, AMM, SMA: data collection and data analysis; TSP: data interpretation; IK: data analysis and manuscript correction.

Conflict of interest: The authors declare that there is no conflict of interest in relation to this study.

Acknowledgements: Dr. Ahmad Babalghith, the Dean, Faculty of Public Health and Health Informatics, and the students of the Umm AlQura University supported this study and authors are grateful to them.

Ethics approval and consent to participate: Ethical approval was obtained from the Ethical Committee of the College prior to carrying out the research work. Participation in the study was voluntary and written consent was taken from every participant.

Availability of data and materials: All data are available in the text.

Received for publication: 16 July 2020

Revision received: 14 November 2020.

Accepted for publication: 14 November 2020.

This work is licensed under a Creative Commons AttributionNonCommercial 4.0 International License (CC BY-NC 4.0).

(C) Copyright: the Author(s), 2020

Licensee PAGEPress, Italy

Health Psychology Research 2020; 8:9263

doi:10.4081/hpr.2020.9263 sion of the Depression, Anxiety, and Stress Scale (DASS-21) validated from the original English version instrument by Lovibond and Lovibond (1995) was used; A sample of 373 respondents through clustered sampling was drawn from the five randomly chosen faculties of the University. Data was analyzed by running ANOVA and t-test procedures in SPSS software. The study found that the prevalence of stress, anxiety, and depression in the students was $30 \%, 60 \%$, and $50 \%$ respectively. A statistically significant difference was found in the stress levels of students of different colleges $(p=0.000)$. Students' stress levels were significantly higher $(\mathrm{p}=0.000)$ in the Applied Medical Sciences and in the final year students $(p=0.015)$. Significantly high levels of depression $(\mathrm{p}=0.000)$, anxiety $(\mathrm{p}=0.000)$, and stress $(\mathrm{p}=0.000)$ were found in the students belonging to the poor economic strata. Depression $(p=0.038)$, Anxiety $(p=0.022)$, and stress $(p=0.001)$ were statistically high in the students whose father had a low level of education. Statistically high level $(\mathrm{p}=0.028)$ of stress was also found in the students whose mothers had a low level of education. Students who reported educational difficulties had significantly $(p=0.001)$ high levels depression. However, the results of stress, anxiety, and depression in married students and the location of the students' variables were not found statistically significant. The findings may be useful for informed policymaking in the higher learning institutions and initiation of counseling provisions in the concerned faculties for the distressed students with a view to enhancing their educational outcomes.

\section{Introduction}

Depression and anxiety disorders are common mental health problems prevalent highly in the population; these disorders impact feelings and mood; its symptoms range from mild to severe and may last from months to years. Globally, around $4.4 \%$ and $3.6 \%$ population suffer from depression and anxiety disorders (WHO, 2017); it remains the topmost reason for students to seek counselling; studies reveal that 1 out of 5 college students suffers from anxiety and the depression (Rosenberg, 2018). The process of education requires sometime separation from the family and friends, this causes fears about the future, these factors have serious bearings on the mental health of the students. Students operate in pressure to succeed, to get lucrative jobs after graduation, and they worry about failures (Lawton, 2019). Stress is one of the topmost known barriers in academic performance amongst all known stress producing determinants such as sore throats, flu, problems to friend or family, and difficulties in relationships (Hussain, 2006). Students in higher education suffer from a high degree of stress and anxiety (Lawton, 2019). 
Prevalence of the depression amongst college going students is as high as $30.6 \%$, substantially higher than found amongst the general population (Ibrahim, Kelly, Adams, \& Glazebrook, 2013); $67 \%$ medical students suffer from the stress owing to high academic pressures (Saudi Gazette, 2017). People with mild and moderate depression experience suicide ideation, severe symptoms increase likelihood of attempts of suicides (Cukrowicz et al., 2011). Suicide is a leading cause of deaths amongst the youths of 15-29 years (WHO, 2017). These mental health problems have severe consequences including school drops out, marital difficulties, and work inefficiency (Astutik et al., 2020). Suicide and depression amongst college going students is a serious cause of concerns; studies show that suicide is the second leading cause of death amongst the college-going students.

Young adults (20-24) with depression are five times more likely to commit suicide than that of normal adults (Childhood Depression Statistics, 2012). In the context of Saudi Arabia, there is a paucity of the literature on the mental health of students. This study was carried out to measure the prevalence of stress, anxiety, and depression and their social determinants amongst undergraduates of Umm Al-Qura University (UQU) with a view to encourage informed strategies and policy making to prevent occurrences of mental disorders and to promote mental health in educational institutions of higher learning in Saudi Arabia.

\section{Materials and Methods}

It's a cross sectional study in which quantitative tools and techniques (ANOVA, t test, Lavene Test, and Post-hoc Tukey's HSD test) were employed for the analysis and interpretation of the data.

\section{Sample}

This study was carried in the Umm Al-Qura University (UQU), a public funded University, based in Makkah, Saudi Arabia during 2018-2019. From the 14 faculties of the UQU, five faculties were selected randomly for data collection. Selected Colleges Deans' were approached for facilitation of data collection. The required sample size, 373 undergraduate students participated in the study. Sample size was calculated by using Rao soft, an online sample size calculator (Raosoft.com, 2004). Regular undergrad students of the UQU were included in the study. Cluster sampling, level of study, was used to collect data. The participants with an average age of 22 years with (a SD of 1.11). They were drawn randomly from the $\mathrm{I}^{\text {st }}(40), \mathrm{II}^{\text {nd }}(93), \mathrm{III}^{\mathrm{rd}}(108)$, and $\mathrm{IV}^{\text {th }}$ (128) levels of the studies. Participants from the faculty of the Applied Medical Sciences (78), Engineering \& Architecture (84), Medicine (40), Public Health (89) and Social Sciences (82) participated in the study. Majority (93\%) and minority (7\%) participants came from urban and rural areas (Table 1). For this cross sectional study, an ethical approval was obtained from the Ethical Committee of the Faculty of Public Health \& Health Informatics UQU, Makkah prior to data collection. Participation in the study was voluntary, however, each participant had to sign the consent letter. Each participant according to their scores was classified as mild, moderate, severe and profound categories under Depression, Anxiety, and Stress domains (Table 2).

\section{Instrument}

The Arabic version of the Depression, Anxiety, and Stress Scale (DASS-21) validated from the original English version

Table 1. Demographic data.

\begin{tabular}{|c|c|}
\hline Variable & Frequency (\%) \\
\hline Age (years), mean $\pm S D$ & $22 \pm 1.11$ \\
\hline $\begin{array}{l}\text { Colleges } \\
\text { Faculty of Medicines } \\
\text { Faculty of Public Health \& Health Informatics } \\
\text { Faculty of Applied Medical Sciences } \\
\text { Faculty of Social Sciences } \\
\text { Faculty of Engineering \& Architecture }\end{array}$ & $\begin{array}{l}40(10.7) \\
89(23.9) \\
78(20.9) \\
82(22.0) \\
84(22.50)\end{array}$ \\
\hline $\begin{array}{l}\text { Year of study (in college) } \\
\text { First year } \\
\text { Second year } \\
\text { Third year } \\
\text { Fourth year }\end{array}$ & $\begin{array}{l}44(11.8) \\
93(24.9) \\
108(29.0) \\
128(34.3)\end{array}$ \\
\hline $\begin{array}{l}\text { Residence } \\
\text { Rural } \\
\text { Urban } \\
\end{array}$ & $\begin{array}{c}347(93.0) \\
26(7.0)\end{array}$ \\
\hline $\begin{array}{l}\text { Income } \\
\quad \leq 3000 \mathrm{SR} \\
3000-8000 \mathrm{SR} \\
>8000 \mathrm{SR}\end{array}$ & $\begin{array}{l}108(29.0) \\
143(38.3) \\
122(32.7)\end{array}$ \\
\hline $\begin{array}{c}\text { Marital status } \\
\text { Single } \\
\text { Married }\end{array}$ & $\begin{array}{c}317(85) \\
56(15)\end{array}$ \\
\hline $\begin{array}{l}\text { Educational difficulties } \\
\text { Yes } \\
\text { No }\end{array}$ & $\begin{array}{c}50(13.4) \\
323(86.6)\end{array}$ \\
\hline $\begin{array}{l}\text { Education (father) } \\
\text { Primary } \\
\text { Intermediate } \\
\text { Secondary } \\
\text { Higher edu } \\
\end{array}$ & $\begin{array}{c}41(11.0) \\
59(15.8) \\
87(23.3) \\
186(49.9)\end{array}$ \\
\hline $\begin{array}{l}\text { Education (mother) } \\
\text { Primary } \\
\text { Intermediate } \\
\text { Secondary } \\
\text { Higher edu } \\
\end{array}$ & $\begin{array}{l}46(12.3) \\
53(14.2) \\
116(31.1) \\
158(42.4)\end{array}$ \\
\hline
\end{tabular}

Table 2. Frequencies of stress, anxiety, and depression.

\begin{tabular}{lccccccccc} 
Category & & Stress & & & Anxiety & & \multicolumn{2}{c}{ Depression } \\
F & $\%$ & Score & F & $\%$ & Score & F & Score \\
Normal & 262 & 70.2 & $0-14$ & 150 & 40.2 & $0-7$ & 187 & 50.1 & $0-9$ \\
Mild & 41 & 11.0 & $15-18$ & 38 & 10.2 & $8-9$ & 85 & 22.8 & $10-13$ \\
\hline Moderate & 42 & 11.3 & $19-25$ & 103 & 27.6 & $10-14$ & 62 & 16.6 & $14-20$ \\
Severe & 24 & 6.4 & $26-36$ & 39 & 10.5 & $15-19$ & 17 & 4.6 & $21-27$ \\
\hline Profound & 4 & 1.1 & $37-42$ & 43 & 11.5 & $20-42$ & 22 & 5.9 & $28-42$ \\
Total & 373 & 100 & & 373 & 100 & & 373 & 100 & \\
\hline
\end{tabular}


instrument by Lovibond \& Lovibond (1995) was used. This is a self-reporting scale with 21 Likert types statements with four alternatives to choose ranging from 0 (didn't apply to me) to 3 (applied to me very much). Each subscale has seven items each. The depression domain of the scale measures hopelessness, dysphoria, worthlessness of life disinterest on pleasurable activities, anhedonia etc. The anxiety domain assesses level of skeletal, muscle arousal and situational anxiety. The stress domain of the scale assesses the level of irritability, difficulty in relaxing, easily being upset or agitated (Moussa, Lovibond, Laube, \& Megahead, 2016). These three subscales have reliability (Cronbach's alpha) of 0.93 , 0.09 , and 0.93 respectively (Gallego, Aguilar-Parra, Cangas, Langer, \& Mañas, 2015). However, this instrument is probabilistic rather deterministic measure of distress (Ali et al., 2017). A separate questionnaire was developed and piloted before its use for gathering the socioeconomic data of the subjects.

\section{Results}

Depression was the highest ( $M=14.51)$ amongst the students of the College of Applied Sciences, followed by the College of Medicines $(M=12.70)$, the College of Engineering \& Architecture $(\mathrm{M}=11.76)$, and the lowest in the College of Social Sciences $(\mathrm{M}=8.76)$. The Anxiety level was the highest in the College of Engineering \& Architecture $(\mathrm{M}=11.76)$ and the College of Medicine and the lowest in the College of Social Sciences and College of Public Health (Figure 1). The Stress level was found to be the highest in the College of Engineering \& Architecture $(M=10.19)$ and the College of Medicine $(M=9.85)$ and the lowest in the College of Public Health $(\mathrm{M}=8.43)$ and the College of Social Sciences $(M=8.78)$. However, on examination of results of oneway analysis of variance procedure, the Depression and Anxiety means scores of the subjects of all the colleges $[F(4,368)=1.71$, $\mathrm{p}=0.147]$ did not differ significantly.

A statistical significant difference was found in the stress levels of students of different colleges $[F(4,368)=6.02, p=0.000]$ (Table 3). Results shows that the stress levels were the highest in the College of Applied Medical Sciences ( $\mathrm{M}=14.51$; $\mathrm{SD}=8.61)$ followed by the College of Medicine $(M=12.70 ; S D=8.43)$. The College of Social Sciences $(\mathrm{M}=8.39$; $\mathrm{SD}=3.91)$ has the lowest stress levels amongst its students. Post-hoc Tukey's HSD tests indicates that the Colleges of Medicine, Applied Medical Sciences, and the College of Public health and Health Informatics differed significantly from the College of Social Sciences in terms of stress levels amongst their students.

One-Way ANOVA procedure found homogeneity of variance of stress means scores (Years' of study) (Lavene Scores) significant $[F(3,369)=6.66 ; p=0.000]$ following which robust test of equality of means Brown Forsythe was run which rejected the null hypothesis $[F(3,369)=3.52 ; p=0.015]$ (Table 3). It implies that the means scores of Years' of Study differs from each other significantly. Results demonstrates that the stress levels are the highest in the Final Year $(\mathrm{M}=13.22 ; \mathrm{SD}=9.47)$ followed by the Third Year $(\mathrm{M}=11.94 ; \mathrm{SD}=07.75)$. The lowest stress level was found in the Second Year students $(M=09.87$; SD 07.98) followed by the First Year students ( $\mathrm{M}=11.18$; $\mathrm{SD}=05.58)$. Post-hoc Tukey's HSD tests indicated that the Fourth Years' stress scores of students differed significantly from the Second Years' students' stress scores. However, no statistical difference was found in the depression and anxiety levels of students of different levels.

Lavene Test found homogeneity of variance of the Depression significant on various incomes groups scores $[F(2,370)=7.02$; $\mathrm{p}=0.000]$ following which the robust test of equality of means the Brown Forsythe was run, which rejected the null hypothesis [F $(2,277)=13.75 ; p=0.000]$ (Table 4). It implies that the means scores of the Depression on different income groups differed from each other significantly. Further, results demonstrate that the depression levels were the highest in the students belonging to families earning less than 3000 Riyals/m $(\mathrm{M}=12.63 ; \mathrm{SD}=9.86)$ followed by the category earning 3000-8000 Riyals/m $(\mathrm{M}=9.54 ; \mathrm{SD}=07.48)$. The least depression level was found in the category earning more than 8000 Riyals/m ( $M=07.12 ; \mathrm{SD}=05.71)$. Post-hoc Tukey's HSD tests indicated that the depression scores of students belonging to lowerincome categories differed significantly from the upper-income group.

Lavene Test found the homogeneity of variance of the Anxiety scores significant on various incomes groups $[\mathrm{F}(2,370)=9.25$; $\mathrm{p}=0.000]$ following which robust tests of equality of means Brown Forsythe was run, which rejected the null hypothesis [F $(2,89)=14.70 ; p=0.000]$ (Table 3$)$. It implies that the means scores of Anxiety on different Income Groups differ from each other significantly. Furthermore, results demonstrated that the Anxiety levels is the highest in the students belonging to the families earning $<3000$ Riyals/m $(\mathrm{M}=12.63 ; \mathrm{SD}=8.62)$ followed by the category earning 3000-8000 Riyals/m ( $\mathrm{M}=8.74 ; \mathrm{SD}=06.31)$. The least Anxiety level was found in the category earning more than 8000 Riyals/m (M=07.86; SD 05.77). Post-hoc Tukey's HSD tests indicated that the Anxiety scores of students on different income category I differed significantly from the category III.

Lavene Test found homogeneity of variance of the Stress scores significant on various incomes groups $[\mathrm{F}(2,370)=9.25$; $\mathrm{p}=0.004$ ] following which robust tests of equality of means Brown Forsythe was run, which rejected the null hypothesis $[\mathrm{F}$ $(2,311)=10.74 ; p=0.000]$ (Table 3$)$. It implies that the means scores of stress on different income groups differ from each other significantly. Furthermore, results demonstrated that the stress level is the highest in the students belonging to the families earning $<3000$ Riyals $/ \mathrm{m}(\mathrm{M}=14.85 ; \mathrm{SD}=9.57)$ followed by the category earning 3000-8000 Riyals/m $(M=10.80 ; S D=7.12)$ and similar results were found in the category earning more than 8000 Riyals $/ \mathrm{m}$

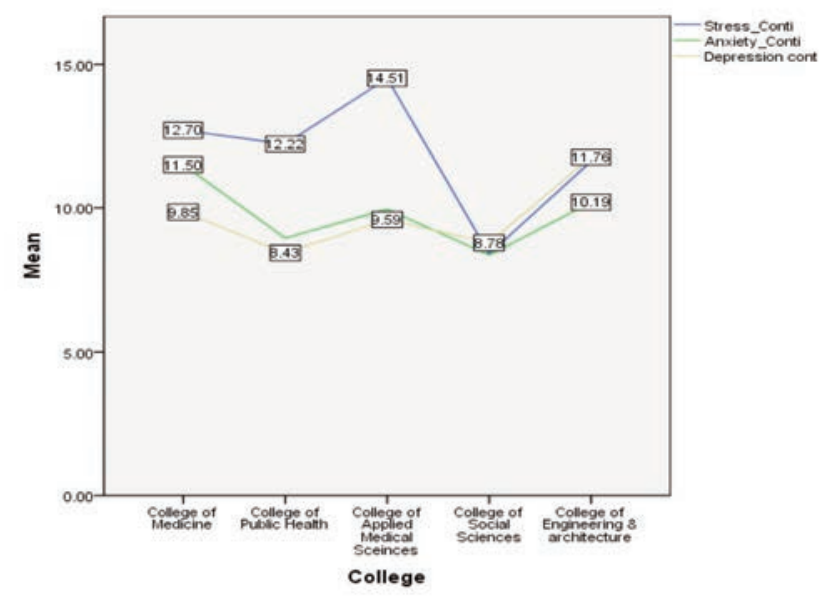

Figure 1. Comparative means of subjects' scores of different Colleges on DASS-21. 
$(M=10.12 ;$ SD 7.65). Post-hoc Tukey's HSD test indicated that the stress of the students on different income category $<3000 / \mathrm{m}$ differed significantly from other two income categories.

The assumption of normality of homogeneity of variance was tested and found tenable using Lavene Test $[\mathrm{F}(3,369)=2.31$; $\mathrm{p}=0.076]$. A statistical significant difference was found in the students' depression levels whose fathers belonged to different educational categories $[\mathrm{F}(3,369)=2.83, \mathrm{p}=0.038]$ (Table 3). Results demonstrates that the depression levels were the highest in the students whose father had intermediate level of education $(M=7.07$; $\mathrm{SD}=10.04$ ) followed by the students' whose father had higher level of education $(\mathrm{M}=10.12 ; \mathrm{SD}=08.26)$. The least level of depression was found in the students' whose father had primary level of education ( $\mathrm{M}=09.87 ; \mathrm{SD}=07.98)$ followed by the students' whose father had secondary level of education $(\mathrm{M}=08.76$; $\mathrm{SD}=08.26)$. Post-hoc Tukey's HSD tests indicated that the students' depression levels whose father had education up to primary levels significantly differed from the students' depression level whose father had education up to intermediate level.

The assumption of normality of homogeneity of variance was tested and found tenable using Lavene Test $[\mathrm{F}(3,369)=2.19$; $\mathrm{p}=0.089]$. The ANOVA was significant $[\mathrm{F}(3,369)=3.26, \mathrm{p}=0.022]$ (Table 3). Thus, there is significant evidence to reject the null hypothesis and conclude that there is significant difference in the anxiety levels of the students whose fathers belonged to different educational categories. Post-hoc Tukey's HSD tests indicated that the students' anxiety levels whose father had education up to primary levels significantly differed from the students' depression level whose father had education up to Intermediate level.

The assumption of normality of homogeneity of variance was tested and found tenable using Lavene Test $[\mathrm{F}(3,369)=0.492$; $\mathrm{p}=0.69)$ for the stress scores. The ANOVA was significant $[\mathrm{F}$

Table 3. Stress in different colleges and stress at different levels of study.

\begin{tabular}{|c|c|c|c|c|c|}
\hline & $\mathbf{N}$ & Mean & SD & $\mathrm{F}$ & P \\
\hline $\begin{array}{l}\text { Different college and stress levels } \\
\text { Medicine } \\
\text { Public Health \& Health Informatics } \\
\text { Applied Medical Sciences } \\
\text { Social Sciences } \\
\text { Engineering \& Architecture }\end{array}$ & $\begin{array}{l}40 \\
89 \\
78 \\
82 \\
84\end{array}$ & $\begin{array}{l}12.70 \\
12.22 \\
14.51 \\
08.39 \\
11.62\end{array}$ & $\begin{array}{l}8.43 \\
9.82 \\
8.61 \\
3.91 \\
8.40\end{array}$ & 6.02 & .000 \\
\hline $\begin{array}{l}\text { Years of study and stress } \\
\text { First } \\
\text { Second } \\
\text { Third } \\
\text { Last }\end{array}$ & $\begin{array}{c}44 \\
93 \\
108 \\
128\end{array}$ & $\begin{array}{l}11.18 \\
09.87 \\
11.94 \\
13.22\end{array}$ & $\begin{array}{c}05.58 \\
07.98 \\
07.75 \\
9.47\end{array}$ & 3.52 & .015 \\
\hline $\begin{array}{l}\text { Depression and income groups } \\
\quad<3000 \text { Riyals/m } \\
3000-8000 \text { Riyals/m } \\
\quad>8000 \text { Riyals/m }\end{array}$ & $\begin{array}{l}108 \\
143 \\
122\end{array}$ & $\begin{array}{c}12.63 \\
9.54 \\
7.12\end{array}$ & $\begin{array}{l}9.86 \\
7.48 \\
5.71\end{array}$ & 13.75 & .000 \\
\hline $\begin{array}{l}\text { Anxiety and income groups } \\
\quad<3000 \text { Riyals/m } \\
3000-8000 \text { Riyals/m } \\
>8000 \text { Riyals/m }\end{array}$ & $\begin{array}{l}108 \\
143 \\
122\end{array}$ & $\begin{array}{l}12.63 \\
08.74 \\
07.86\end{array}$ & $\begin{array}{l}8.62 \\
6.31 \\
5.77\end{array}$ & 14.70 & .000 \\
\hline $\begin{array}{l}\text { Stress and income groups } \\
\quad<3000 \text { Riyals/m } \\
\text { 3000-8000 Riyals/m } \\
>8000 \text { Riyals/m }\end{array}$ & $\begin{array}{l}108 \\
143 \\
122\end{array}$ & $\begin{array}{l}14.85 \\
10.80 \\
10.20\end{array}$ & $\begin{array}{l}9.57 \\
7.17 \\
7.65\end{array}$ & 228.8 & .000 \\
\hline $\begin{array}{l}\text { Depression and education category } \\
\text { Primary } \\
\text { Intermediate } \\
\text { Secondary } \\
\text { Higher education }\end{array}$ & $\begin{array}{c}41 \\
59 \\
87 \\
186\end{array}$ & $\begin{array}{c}7.07 \\
11.29 \\
8.76 \\
10.12\end{array}$ & $\begin{array}{c}6.99 \\
10.04 \\
5.97 \\
8.26\end{array}$ & 2.83 & .038 \\
\hline $\begin{array}{l}\text { Anxiety and education category } \\
\text { Primary } \\
\text { Intermediate } \\
\text { Secondary } \\
\text { Higher education }\end{array}$ & $\begin{array}{c}41 \\
59 \\
87 \\
186\end{array}$ & $\begin{array}{l}07.61 \\
13.08 \\
13.52 \\
11.46\end{array}$ & $\begin{array}{l}6.80 \\
9.06 \\
8.17 \\
8.12\end{array}$ & 3.26 & .022 \\
\hline $\begin{array}{l}\text { Stress and education category } \\
\text { Primary } \\
\text { Intermediate } \\
\text { Secondary } \\
\text { Higher education }\end{array}$ & $\begin{array}{c}41 \\
59 \\
87 \\
186\end{array}$ & $\begin{array}{c}7.61 \\
13.08 \\
13.52 \\
11.46\end{array}$ & $\begin{array}{l}6.80 \\
9.06 \\
8.17 \\
8.11\end{array}$ & 5.49 & .001 \\
\hline $\begin{array}{l}\text { Stress and mothers' education } \\
\text { Primary } \\
\text { Intermediate } \\
\text { Secondary } \\
\text { Higher education } \\
\end{array}$ & $\begin{array}{c}46 \\
53 \\
116 \\
158 \\
\end{array}$ & $\begin{array}{c}8.82 \\
13.55 \\
12.43 \\
11.56 \\
\end{array}$ & $\begin{array}{c}6.9 \\
8.07 \\
8.91 \\
8.12 \\
\end{array}$ & 3.07 & .028 \\
\hline
\end{tabular}


$(3,369)=5.49, p=0.001]$ (Table 3$)$. Thus, there is significant evidence to reject the null hypothesis and conclude that there is significant difference in the stress levels of the students whose fathers belonged to different educational categories. Stress levels were the highest in the students' whose father had secondary level of education $(\mathrm{M}=13.52 ; \mathrm{SD}=8.72)$ followed by the students' whose father had intermediate level of education $(M=13.08 ; \mathrm{SD}=9.06)$. The least level of stress was found least in the students' whose father had primary level of education ( $M=7.61$; SD 6.80) followed by the students' whose father had higher level of education $(\mathrm{M}=11.46$; $\mathrm{SD}=8.11$ ). Post-hoc Tukey's HSD tests indicated that the students' stress levels whose father had education up to primary levels significantly differed from all other categories.

No significant results were obtained from the ANOVA procedure for the depression and the anxiety levels of mothers belonging to the different education categories. However, the assumption of normality of homogeneity of variance for the stress scores of mothers of different education categories was tested and found tenable using the Lavene Test $[\mathrm{F}(3,369)=0.400 ; \mathrm{p}=0.75]$. The ANOVA was significant $[\mathrm{F}(3,369)=3.07, \mathrm{p}=0.028]$ (Table 3). Thus, there is significant evidence to reject the null hypothesis and conclude that there is significant difference in the stress levels of the students whose mothers belonged to different educational categories. Stress levels were the highest in the students' whose mothers had intermediate level of education $(M=13.55$; $S D=8.07)$ followed by the students' whose mothers had a secondary level of education $(\mathrm{M}=12.43 ; \mathrm{SD}=8.91)$. The lowest level of stress was found in the students' whose mothers had a primary level of education ( $\mathrm{M}=8.82 ; \mathrm{SD}=6.90)$, followed by the students' whose mothers had a higher level of education ( $\mathrm{M}=11.56$; $\mathrm{SD}=8.12)$. Post-hoc Tukey's HSD tests indicated that the students' stress levels whose mothers had education up to a primary level significantly differed from all other categories

The depression, anxiety, and stress levels of the students living with family and away from the family, married or unmarried, with chronic disease or without chronic disease were not found statistically significant. However, the results obtained from the independent $\mathrm{t}$-test, $[\mathrm{t}(371)=3.32, \mathrm{p}=0.001]$ about depression levels of students who reported having educational difficulties $(M=13.2$, $\mathrm{SD}=8.41$ ) were significantly different from the students who did not report educational difficulties $(M=9.12, \mathrm{SD}=9.11)$. No significant results were obtained with regard to the anxiety and stress of the students who reported educational difficulties (Table 4).

\section{Discussion}

Study found that $30 \%$ students were stressed, $60 \%$ had anxiety, and $50 \%$ had depression of various degrees of various faculties of the University. A similar study conducted in an Indonesian university reported that the prevalence of depression, heightened anxiety, and stressed were $25 \%, 51 \%$, and around $40 \%$ (Astutik et al., 2020). A web-based survey in Hong Kong reported the prevalence of depression, anxiety, and stress in the students were $21 \%, 41 \%$, and 27\% (Wong et al., 2006), and a cross sectional study in Jazan University concluded that the students suffered from the depres- sion (54\%), anxiety (66\%) and stress (34\%) respectively (Al Bahhawi et al., 2018). A Malaysian study found the heightened depression ( $27.5 \%$ moderate and $9.7 \%$ severe), anxiety ( $34 \%$ moderate and $29 \%$ severe), and stress (18.6\% moderate and $5.1 \%$ severe) respectively in the university's students (Shamsuddin et al., 2013). Findings of this study are in consistency with the other studies; however, minor difference in the findings can be attributed to methodological and cultural differences. Students of the Colleges Medical Sciences had the highest stress levels. Similar findings have been reported that the medical students are stressed due to academic pressures (Alsalhi, Almigbal, Alsalhi, Batai, 2018; Altannir et al., 2019; Shim et al., 2016).

A study in Brazil found that the medical students have higher degree depression, anxiety and emotional problems and the final years' students were the most stressed in the entire years' of study programs (Moutinho, Lucchetti Ezequiel, \& Lucchetti, 2019). A study concluded that the pressure to succeed, academic performance were major concerns amongst final year students (Beiter et al., 2015). Saudi Gazette reported that Saudi medical graduates enjoy high social status, however, it comes with the cost in the form of stressful heavy workload and majority of their time is spent in academic activities; stress, anxiety and depression is common amongst medical students (Saudi Gazette, 2017).

Researches also report that the more the academic load, the more pressures on students; it requires a great degree of balancing act on the part of a student in his or her personal life, exam preparation, writing various exams, financial and social life, family life and bearing pressures from extracurricular activities (Astutik et al., 2020). The Study also finds that the students of the faculty of the Engineering and Architecture were significantly stressed. A study conducted in India established that the undergraduate students of engineering were significantly stressed (Parvez \& Agrawal, 2018).

This study found the significantly high levels of depression, anxiety, and stress were found in the students belonging to the poor economic strata. Similar results were reported in a study carried out in South Africa, which stated that the people in resource poor settings are more depressed and stressed (Hamad, Fernald, Karlan, \& Zinman, 2008). A study conducted in Egypt stated that the students from poor families are more likely to develop depression and report for the suicidal ideation (Wafaa \& Safaa, 2017). The likelihood of developing depression 4 times higher and developing anxiety 6 times higher in medical students than the students of other faculties (Hamad et al., 2008).

Students who reported educational difficulties were found to have significantly higher scores on depression than that of their counterparts who did not report educational problems. A Russian study which reported the similar results that the difficulty in studies, inadequacy in sleep, and poor coping skills creates stress to medical students (Ruzhenkova, Tarabaeva, Ruzhenkov, \& Lukyantseva, 2018). However, the effect size estimated 0.46 is a small size effect in the behavioral social sciences (Sawilowsky 2009). The depression, anxiety and stress levels of the students living with family and away from the family, married or unmarried, with a chronic disease or without a chronic disease were not found statistically significant.

Table 4. Students' depression facing educational difficulties.

\begin{tabular}{lccccc} 
Depression and educational difficulties in students & Mean & SD & P Effect Sire (d) \\
Yes & 13.12 & 8.41 & 3.32 & .001 & 0.46 \\
No & 9.12 & 9.11 & & \\
\hline
\end{tabular}




\section{Conclusions}

The present study found that the students of medical sciences and engineering had heightened levels of depression, anxiety and stress. First and the third year students were more depressed, anxious and stressed. Students from resource poor and low educational level families had depression, anxiety, and stress. Students facing educational difficulties were also had high degree of depression. The findings of the study can be used for the informed policymaking and initiation of counselling provisions in the concerned faculties particularly in the faculties of medical sciences and engineering.

\section{References}

Al Bahhawi, T., Albasheer, O.B., Makeen, A.M., Arishi, A.M., Hakami, O.M., Maashi, S.M., Al-Khairat, H.K., Alganmy, O.M., Sahal, Y.A., Sharif A.A., Mahfouz MS (2018). Depression, anxiety, and stress and their association with khat use: a cross-sectional study among Jazan University students, Saudi Arabia. Neuropsychiatric Disease and Treatment, 14, 2755-2761.

Ali, A. M., Ahmed, A., Sharaf, A., Kawakami, N., Abdeldayem, S. M., \& Green, J. (2017). The Arabic Version of The Depression Anxiety Stress Scale-21: Cumulative scaling and discriminantvalidation testing. Asian journal of psychiatry, 30, 56-58.

Alsalhi, A. H., Almigbal, T.H., Alsalhi, H. H., Batai, M. A. (2018). The Relationship between Stress and Academic Achievement of Medical Students in King Saud University: A CrossSectional Study. Kuwait Medical Journal, 50(1):60-5.

Altannir, Y., Alnajjar, W., Ahmad, S. O., Altannir, M., Yousuf, F., Obeidad, A., Al-Tannir, M. 2019. Assessment of burnout in medical undergraduate students in Riyadh, Saudi Arabia. BMC Medical Education, 19(1), 2-8.

Astutik, E., Sebayang, S. K., Puspikawati, S. I., Tama, T. D., Sintha, D. M.,Dewi, K. (2020). Depression, Anxiety, and Stress among Students in Newly Established Remote University Campus in Indonesia. Malaysian Journal of Medicine and Health Sciences, 16(1), 270-277.

Beiter, R., Nash, R., McCrady, M., Rhoades, D., Linscomb, M., Clarahan, M., \& Sammut, S. (2015). The prevalence and correlates of depression, anxiety, and stress in a sample of college students. Journal of Affective Disorders, 173, 90-6.

Childhood Depression Statistics, 2012. Teen Depression Statistics, Prevention, Facts On Teenage Depression. Available from: http://www.teendepression.org/stats/depression-in-college studentsstatistics/. Accessed 15 July 2020.

Cukrowicz, K. C., Schlegel, E. F., Smith, P. N., Jacobs, M. P., Van Orden, K. A., Paukert, A. L., Pettit, J. W., \& Joiner, T. E. (2011). Suicide ideation among college students evidencing subclinical Depression. Journal of American College Health, 59(7), 575-581.

Gallego, J., Aguilar-Parra, J. M., Cangas, A. J., Langer, Á. I., \& Mañas, I. (2015). Effect of a mindfulness program on stress, anxiety and depression in university students. The Spanish journal of psychology, 17, E109

Hamad, R., Fernald, L. C., Karlan, D. S., \& Zinman, J. (2008). Social and economic correlates of depressive symptoms and perceived stress in South African adults. Journal of epidemiology and community health, 62(6), 538-544.

Ibrahim, A. K., Kelly, S. J., Adams, C. E., \& Glazebrook, C. (2013). A systematic review of studies of depression preva- lence in university students. Journal of psychiatric research, 47(3), 391-400.

Lawton G, 2019. Why are students at university so stressed? [Internet]. The Guardian. Guardian News and Media. Accessed 2020 Apr 3. Available from: https://www.theguardian.com/education/2019/may/31/whyare-students-at-university-so-stressed

Moussa, M. T., Lovibond, P., Laube, R., \& Megahead, H. A. (2016). Psychometric Properties of an Arabic Version of the Depression Anxiety Stress Scales (DASS). Research on Social Work Practice, 27(3), 375-386.

Moutinho, I., Lucchetti, A., Ezequiel, O., \& Lucchetti, G. (2019). Mental health and quality of life of Brazilian medical students: Incidence, prevalence, and associated factors within two years of follow-up. Psychiatry research, 274, 306-312.

Parvez M, \& Agrawal M, 2018. Anxiety, Depression and Stress Among Undergraduate Students: a Comparative Study of Mathematics and Engineering Students. Journal of Advances and Scholarly Researches in Allied Education, 15(7):192-7.

Raosoft.com, 2004. Sample Size Calculator By Raosoft, Inc.. [online] Available at: http://www.raosoft.com/ samplesize.html. Accessed 15 July 2020.

Rosenberg D., 2018. 1 In 5 College Students Have Anxiety Or Depression. Here's Why. [online]. The Conversation. Available from: http://theconversation.com/1-in-5-college-studentshave-anxiety-ordepression-heres-why-90440. Accessed 15 July 2020.

Saudi Gazette, 2017. 67\% Saudi Medical Students Suffer Due To Stress. [online] Available from: http://saudigazette.com.sa/article/519378. Accessed 15 July 2020.

Sawilowsky, S., 2009. New Effect Size Rules Of Thumb. [online] DigitalCommons@WayneState. Available from: https://digitalcommons.wayne.edu/coe_tbf/4/. Accessed 15 July 2020.

Shamsuddin, K., Fadzila, F., Ismail, W. S. W., Shah, S. A., Omar, K., Muhammad, N. A., Jaffar, A., Ismail, A., Mahadevan, R. (2013). Correlates of depression, anxiety and stress among Malaysian university students. Asian Journal of Psychiatry, 6(4), 318-323.

Shim, E-J, Jeon, H. J., Kim, H., Lee, K-M., Jung, D., Noh, H-L., Roh, M-S., Hahm, B-J. (2016). Measuring stress in medical education: validation of the Korean version of the higher education stress inventory with medical students. BMC Medical Education, 16(1), 302.

Ruzhenkova, V. V., Tarabaeva, V. B., Ruzhenkov, V. A., \& Lukyantseva, I. S. (2018). Medical and psychological characteristics of the 1st year students of medical and pedagogical institutes and their features of educational adaptation. Drug Invention Today, 10(3), 3240-3246.

Wafaa, Y. W., \& Safaa, H. K. (2017). Prevalence and associated factors of stress, anxiety and depression among medical Fayoum University students. Alexandria Journal of Medicine, 53, 77-84.

WHO. 2017. Depression and other common mental disorders. Available from: https://apps.who.int/iris/bitstream/handle/10665/254610/WH O-MSD-MER-2017.2-eng.pdf. Accessed 15 July 2020.

Wong, J. G., Cheung, E. P., Chan, K. K., Ma, K. K., \& Tang, S. W. (2006). Web-based survey of depression, anxiety and stress in first-year tertiary education students in Hong Kong. The Australian and New Zealand journal of psychiatry, 40(9), $777-$ 782 . 